This is the accepted manuscript of the article, which has been published in Women's History Review. 2019, 28(6), 950-966. https://doi.org/10.1080/09612025.2018.1516243

\title{
Maternalism and Workhouse Matrons in Nineteenth-Century Finland
}

Johanna Annola

University of Tampere

Faculty of Social Sciences

33014 University of Tampere

Finland

Email: johanna.annola@uta.fi

Mobile: +358503186058

This article uses the concept of maternalism to discuss workhouse management, which in late nineteenth-century Finland was entrusted to women. The article looks at the ways in which maternalist discourse manifests in the development of a workhouse matron's leadership position, how the said discourse became further manifest in the guidelines given to matrons by the state poor relief officials and how the boundaries of a matron's authority were defined in conflicts with both male agents in poor relief and the paupers themselves. Ultimately, the article illuminates the contemporary understanding of feminine and masculine duties in society, which were inextricably linked to perceptions of social class. In addition, it explores the transfer of ideas from the more central regions of Europe to a Northern periphery by contrasting the Finnish development with that in England. The 
article suggests that as a workhouse matron's position was built on the ideal of normative womanhood, it was not emancipatory per se. However, the article also shows that only those elements of normative womanhood that were relevant to a matron's mission of converting the paupers to respectable citizenship were to be included in her leadership as a whole. These restrictions marked professionalization inside the contemporary maternalist discourse and the feminine sphere of society.

Keywords: social care work, poor relief, workhouse, maternalism,

Author biography: Dr Johanna Annola is a Research Fellow at the Academy of Finland Centre of Excellence in History of Experiences, University of Tampere. Her publications in English include works on the relationship between early social care work and women's social mobility in Finland as well as on the development of state control of poor relief in Northern Europe. 


\section{Introduction}

The management of this workhouse has been trusted into the hands of an educated young woman. In her small realm, she is surrounded by love and respect. The inmates think of her as their motherly friend. Not one of them challenges her orders but follows them without hesitation. [--] The institution is characterised by a homely atmosphere. ${ }^{1}$

These lines, originally published in the Finnish Women's Association's journal in 1891, were written by the highest state official for poor relief. They convey the contemporary Finnish ideal of workhouse management: an educated woman, a matron, who was the head of the workhouse staff and in charge of the institution in its entirety. ${ }^{2}$ An arrangement like this was not common in nineteenth-century Northern Europe. For example, English workhouses were in most cases managed by a master, whose primary duty was to maintain order and discipline in the institution. The master was normally assisted by a matron, who dealt with housekeeping matters. ${ }^{3}$

This article discusses the leadership role of a Finnish workhouse matron by employing the concept of maternalism as an analytical tool. Since the early 1990s, scholars have used

\footnotetext{
${ }^{1}$ Gustaf Adolf Helsingius (1891) Nainen vaivaishoidon palveluksessa, Koti ja Yhteiskunta, November 15.

${ }^{2}$ Mirja Satka (1994) Sosiaalinen työ peräänkatsojamiehestä hoivayrittäjäksi, in Jouko Jaakkola, Panu Pulma, Mirja Satka \& Kyösti Urponen (Eds.) Armeliaisuus, yhteisöapu, sosiaaliturva: Suomalaisen sosiaaliturvan historia (Helsinki: Sosiaaliturvan keskusliitto), 261-263; Panu Pulma (1995) Valtio, vaivaiset ja kuntien itsehallinto: Gustaf Adolf Helsingius valtion ja kuntien välisen suhteen muokkaajana, in Seppo Tiihonen (Ed.) Virkanyrkit ja muita hallintohistorian tutkielmia (Helsinki: Painatuskeskus), 117; Johanna Annola (2011) Äiti, emäntä, virkanainen, vartija: köyhäintalojen johtajattaret ja yhteiskunnallinen äitiys 1880-1918 (Helsinki: Finnish Literature Society).

${ }^{3}$ Margaret Crowther (1981) The Workhouse System: the History of an English Social Institution (London: Batsford), 113 , 117, 130; Norman Longmate (2003) The Workhouse: A Social History. Second edition (London: Pimlico), 101; Simon Fowler (2014) The Workhouse: the People, the Places, the Life Behind Doors (Barnsley: Pen \& Sword), 53. It should be noted, however, that in seventeenth-century London there existed official or semi-official parish houses, which were managed by female nurses. The parish houses were multipurpose institutions, which accommodated sick, homeless and mentally ill paupers and provided care for pregnant women. The institutions were superseded by Old Poor Law workhouses after the $1720 \mathrm{~s}$, but some of the nurses continued their work in the workhouses under the title of matron. Moreover, in some cases private almshouses, too, were taken care of by a nurse. Jeremy Boulton (2007) Welfare Systems and the Parish Nurse in Early Modern London, 1650-1725, Family \& Community History, vol. 10 no. 2, 136, 147-149; Alannah Tomkins (2011) Retirement from the Noise and the Hurry of the World? The Experience of Almshouse Life, in Joanne McEwan \& Pamela Sharpe (Eds.) Accommodating Poverty: The Housing and Living Arrangements of the English Poor, c. 1600-1850 (New York \& London: Palgrave Macmillan), 273.
} 
maternalism as an umbrella term to describe both the gendered attributes and ideologies associated with women's agency and the agency itself. ${ }^{4}$ Welfare historians have typically employed maternalism to refer simultaneously to programmes aimed at helping mothers and children, and to women's activism directed at realising these programmes. However, as Rebecca Jo Plant and Marian van der Klein state, the maternalist discourse has also been used to serve more conservative ends - to perpetuate the existing gender or class hierarchies. $^{5}$

The article follows in the footsteps of Seth Koven and Sonya Michel in defining maternalism as a discourse based on a nineteenth-century understanding of a woman's capacity to mother. Maternalism extolled the virtues of domesticity and a woman's 'natural' place in the domestic sphere, but at the same time it also legitimized female agency in the public sphere by extending the values of morality and care to society as a whole. Thus maternalist ideologies both exalted traditional or 'true' womanhood and challenged the boundaries between the gendered private and the public spheres. $^{6}$

The article contributes to the discussion on the relationship between maternalism and female agency by exploring first the ways in which maternalist discourse was bound to the

\footnotetext{
${ }^{4}$ The early works on this field include for instance Gisela Bock \& Pat Thane (Eds.) (1990) Maternity and Gender Policies: Women and the Rise of the European Welfare States, 1880s-1950s (New York \& London: Routledge): Linda Gordon (Ed.) (1990) Women, the State, and Welfare (Madison: University of Wisconsin Press); Seth Koven \& Sonya Michel (1990) Womanly Duties: Maternalist Policies and the Origins of Welfare States in France, Germany, Great Britain, and the United States, American Historical Review, vol. 95, no 4, 1076-1108; Theda Skocpol \& Gretchen Ritter (1991) Gender and the Origins of Modern Social Policies in Britain and the United States, Studies in American Political Development, vol. 5, no. 1, 36-93; Theda Skocpol (1992) Protecting Soldiers and Mothers: The Political Origins of Social Policy in the United States (Cambridge: Harvard University Press); Seth Koven \& Sonya Michel (Eds.) (1993) Mothers of a New World: Maternalist Politics and the Origins of Welfare States (New York: Routledge).

${ }^{5}$ Rebecca Jo Plant \& Marian van der Klein (2012) Introduction: a New Generation of Scholars on Maternalism, in Marian van der Klein, Rebecca Jo Plant, Nichole Sanders \& Lori R. Weintrob (Eds.) Maternalism Reconsidered: Motherhood, Welfare and Social Policy in the Twentieth Century (New York \& Oxford: Berghahn Books), 4. Koven and Michel argue that in some cases male politicians used maternalist rhetoric as a mere cloak for paternalism. Koven \& Michel, Womanly Duties, 1092.

${ }^{6}$ Koven \& Michel, Womanly Duties, 1079; Seth Koven \& Sonya Michel (1993) Introduction: 'Mother Worlds', in Seth Koven \& Sonya Michel (Eds.) (1993) Mothers of a New World: Maternalist Politics and the Origins of Welfare States (New York: Routledge), 1-42. Since the 1990s, Koven's and Michel's approach has been criticized for assuming that motherhood as a common instinct unified all women regardless of their social class and ethnicity, and for ignoring other possible contexts of women's self-identity. Their definition of maternalism as a discourse, however, is nevertheless useful. For an overview of criticism of Koven's and Michel's approach, see Marjaana Niemi (2007) Public Health and Municipal Policy Making: Britain and Sweden, 1900-1940 (Aldershot: Ashgate), 161-162.
} 
development of a workhouse matron's leadership position in Finland. ${ }^{7}$ Second, the article looks at a matron's everyday maternalism with an emphasis on the entanglement of motherly power and care. Ultimately, then, it shows how understandings of feminine and masculine duties that were closely linked to ideas about class underpinned both the ideal and practice of workhouse management.

As a Northern European periphery, Finland offers a good case study on the spread of ideological innovations such as the poor law reform or the maternalist discourse. In this article the development in Finland is contrasted with that of England. This is because the English Poor Law of 1834 and the landmark of institutional care for the poor - the workhouse - were taken as a model in Finland.

The passing in England and Wales ${ }^{8}$ of the New Poor Law (NPL) of 1834 marked an attempt at excluding the able-bodied poor from the right to gratuitous poor relief. Paupers were no longer to be given outdoor relief (money or other aid) but placed in a workhouse where they would work for their maintenance. Both countries were divided into Poor Law Unions, each of which was responsible for establishing a workhouse. The New Poor Law workhouse was to replace the existing poor relief institutions, such as parish poorhouses and older workhouses, which had been established after the passing of the Workhouse Act of $1722 / 1723 .{ }^{9}$ In practice, the transfer from the old institutions to the new ones was slow and gradual, as the Unions proved slow to abandon their old poor relief practices and state authorities often lacked staff and the resources to encourage local Boards of Guardians. ${ }^{10}$

\footnotetext{
${ }^{7}$ For a recent overview of the field, see Plant \& van der Klein, Introduction, 1-21. For earlier overviews, see Annelise Orleck (1997) Tradition Unbound: Radical Mothers in International Perspective, in Alexis Jetter, Annelise Orleck \& Diana Taylor (Eds.) The Politics of Motherhood: Activist Voices from Left to Right (Hanover: University Press of New England), 3-20; Anette Borchorst (2000) Feminist Thinking about the Welfare State, in Myra Marx Ferree, Judith Lorber \& Beth B. Hess (Eds.) Revisioning Gender (Walnut Creek: Altamira Press), 99-126.

${ }^{8}$ This article concentrates on Finland and England, because most British works on the New Poor Law deal with England instead of Wales.

${ }^{9}$ John Broad (2000) Housing the Rural Poor in Southern England, 1650-1850, The Agricultural History Review, vol. 48, no. 2, 167; Steven King (2000) Poverty and Welfare in England, 1700-1850: A Regional Perspective (Manchester: Manchester University Press), 24.

10 King, Poverty and Welfare in England, 66-67; Marjorie Levine-Clark (2000) Engendering Relief: Women, Ablebodiedness and the New Poor Law in Early Victorian England, Journal of Women's History, vol. 11, no. 4 (Winter), 109; Geoff Hooker (2013) Llandilofawr Poor Law Union 1836-1886: 'The Most Difficult Union in Wales'. PhD thesis,
} 
The picture of the Old Poor Law workhouses is mixed. On the one hand, research has shown that there were fairly advanced workhouses, which provided paupers with shelter and medical care. ${ }^{11}$ On the other hand, scholars have described the older institutions as chaotic because of inadequate buildings, poor sanitation, bad or nearly non-existent management and limited resources. In addition, little or no work was often required of the inmates. ${ }^{12}$ The New Poor Law workhouses, in contrast, were - at least in theory - to be overseen by a resident governor, have a medical officer and large staff, and enforce strict discipline. All able-bodied inmates were put to work. According to the principle of 'less eligibility', the overall conditions in the New Poor Law workhouses were to be of a standard below that of an industrious labourer so that paupers would prefer to earn their living instead of resorting to poor relief. Thus, the workhouse system would reduce the costs of poor relief to the ratepayers. $^{13}$

The English Poor Law of 1834 inspired a wave of poor relief reforms, which reached the Nordic Countries in the 1860-70s. In Finland, a new Poor Relief Act was passed in 1879 and a network of workhouses was established from the 1880 s onwards. ${ }^{14}$ In comparison to the English

Centre for English Local History, University of Leicester, 3-6, 290-291, 298; Jonathan Reinarz \& Leonard Schwarz (2013) Introduction, in Jonathan Reinarz \& Leonard Schwarz (Eds.) Medicine and the Workhouse (Rochester: University of Rochester Press), 3. Parish poorhouses and workhouses coexisted side by side with private almshouses, which provided care for the so-called deserving poor. Making a distinction between tax-funded and private institutions can be difficult, because some of the private institutions would also receive public funding from time to time. Tomkins, Retirement from the Noise, 263; Nigel Goose \& Henk Looijesteijn (2012) Almshouses in England and the Dutch Republic circa 13501800: A comparative perspective, Journal of Social History, vol. 45, no. 4, 1052-1053; Nigel Goose (2014) Accommodating the Elderly Poor: Almshouses and the mixed economy of welfare in England in the second millennium, Scandinavian Economic History Review, vol. 62, no 1, 49-50.

11 Jane Humphries (2013) Care and Cruelty in the Workhouse: Children's Experiences of Residential Poor Relief in Eighteenth- and Nineteenth-Century England, in Nigel Goose \& Katrina Honeyman (Eds.) Childhood and Child Labour in Industrial England: Diversity and Agency, 1750-1914 (New York \& London: Routledge), 123-124; as well as the following three contributions in Jonathan Reinarz \& Leonard Schwarz (Eds.) Medicine and the Workhouse (Rochester: University of Rochester Press): Susannah Ottaway (2013) The Elderly in the Eighteenth-Century Workhouse, 47-52; Jeremy Boulton, Romola Davenport \& Leonard Schwarz (2013) 'These Ante-Chambers of the Grave'? Mortality, Medicine, and the Workhouse in Georgian London, 1725-1824, 74, 80; Alannah Tomkins (2013) Workhouse Medical Care from Working-Class Autobiographies, 1750-1834, 91-99.

${ }^{8}$ Robert Dryburgh (2003) The Mixed Economy of Welfare: The New Poor Law and Charity in Mid-Nineteenth Century England. PhD thesis, University of Oxford; Humphries, Care and Cruelty in the Workhouse, 119; Steven King (2013) Poverty, Medicine and the Workhouse in the Eighteenth and Nineteenth Centuries: An Afterword, in Jonathan Reinarz \& Leonard Schwarz (Eds.) Medicine and the Workhouse (Rochester: University of Rochester Press), 236.

${ }^{13}$ Derek Fraser (2009) The Evolution of the British Welfare State: a History of Social Policy since the Industrial Revolution, $4^{\text {th }}$ edition (London: Palgrave Macmillan), 52-55.

${ }^{14}$ Between 1809 and 1917, Finland was a part of the Russian Empire as an autonomous Grand Duchy with a central administration and legislative bodies of its own. The English Poor Law of 1834 was discussed in Finland prior to the passing of the Finnish Poor Relief Act of 1852, but the foreign model was eventually abandoned as too harsh. It took the 
workhouses, the Finnish ones were significantly smaller. The English Poor Law Unions usually comprised some thirty parishes. Each workhouse was intended to serve a population of 10,000 and could in most cases accommodate several hundred inmates. ${ }^{15}$ Most Finnish workhouses, in turn, were established by individual municipalities. ${ }^{16}$ As municipalities were often large but sparsely populated, one workhouse had to serve an average population of a couple of thousand people. While the largest urban workhouses were usually designed for 100-200 inmates, rural institutions usually had capacity for as few as 15 to 40 inmates. ${ }^{17}$

Similar to the English New Poor Law workhouses, the Finnish ones were to replace both outdoor relief and earlier attempts at indoor relief. These included parish poorhouses, which in most cases were mere cottages in which the parish poor lived unattended. The workhouses, in contrast, were to be preferably constructed according to blueprints specified by the state poor relief officials, and always taken care of by a resident master or matron. The inmates were to be subjected to strict discipline and a workhouse diet, which was based on the principle of 'less eligibility'. Similar to English and Welsh workhouses, the able-bodied inmates performed work that was directly involved in the running of the institution, such as cleaning or laundry. However, while in England inmates were often engaged in small industry such as wood-chopping, stone-breaking and oakumpicking, in Finland they worked mostly in agriculture, forestry and animal husbandry as the majority of Finnish workhouses were functioning farms, located in rural areas. ${ }^{18}$

\footnotetext{
catastrophic famine of the 1860 s, followed by burgeoning poor relief costs before the Finnish legislators, too, embraced the idea of a stricter poor law. Panu Pulma (1994) Vaivaisten valtakunta, in Jouko Jaakkola, Panu Pulma, Mirja Satka \& Kyösti Urponen (Eds.) Armeliaisuus, yhteisöapu, sosiaaliturva: Suomalaisen sosiaaliturvan historia (Helsinki: Sosiaaliturvan keskusliitto), 67-68; Jouko Jaakkola (1994) Sosiaalisen kysymyksen yhteiskunta, in Jouko Jaakkola, Panu Pulma, Mirja Satka \& Kyösti Urponen (Eds.) Armeliaisuus, yhteisöapu, sosiaaliturva: Suomalaisen sosiaaliturvan historia (Helsinki: Sosiaaliturvan keskusliitto), 110-113.

${ }^{15}$ Longmate, The Workhouse, 64, 88.

${ }^{16}$ Municipalities were formed after the passing of Municipal Government Act of 1865 , and the responsibility for poor relief was transferred from the ecclesiastical authorities (the parish) to the municipal administration. However, the change was not abrupt, as in most cases the boundaries of municipalities were congruent with those of a parish of the same name, and the Vicar had the right to participate in the decision-making in the regular Poor Relief Board meetings.

${ }^{17}$ Annola, Äiti, emäntä, virkanainen, vartija, 62-63.

18 Jaakkola, Sosiaalisen kysymyksen yhteiskunta, 138; Longmate, The Workhouse, 251-256; Annola, Äiti, emäntä, virkanainen, vartija, 37-38, 61-62, 66, 192-195, 171-172; Fowler, The Workhouse, 88-90.
} 
Earlier research on Finnish poor law reform has highlighted some key differences between industrialised, urbanised and densely populated England and agrarian, sparsely inhabited Finland. It has been suggested that Finnish intelligentsia was particularly keen to adopt the English model because they saw it as a remedy for the backwardness of their home country. ${ }^{19}$ Yet research has shown that the English model was far from ideal for Finland, partly because the majority of indoor paupers were old and sick. With too few people to make workhouses self-supporting, the institutions soon became an economic burden on the municipalities. ${ }^{20}$ What the research has largely ignored, however, is the ways in which both international models and domestic particularities affected the management of poor relief institutions.

The source material for this article consists of documents produced by the Finnish state officials administrating poor relief. These include, first, booklets and guidebooks intended for workhouse directors and local Poor Relief Boards. The two guidebooks published in 1899 and 1917 are especially important. Second, the source material consists of state officials' statements and workhouse inspection protocols as well as the correspondence between the Inspectorate and locallevel agents such as Poor Relief Boards, individual matrons, other members of workhouse staff and even paupers. On the one hand, the material provides information on the ways in which the Inspectorate transmitted its ideology to the grassroots level. On the other, the first-hand accounts of workhouses reveal conflicts between ideology and practice.

\footnotetext{
${ }^{19}$ Pauli Kettunen (2006) The Power of International Comparison: a Perspective on the Making and Challenging of the Nordic Welfare, in Niels Finn Christiansen (Ed.) The Nordic Model of Welfare: a Historical Reappraisal, (Copenhagen: Museum Tusculaneum Press), 37-38; Pirjo Markkola (2007) Changing Patterns of Welfare: Finland in Nineteenth and Early Twentieth Centuries, in Steven King \& John Stewart (Eds.) Welfare Peripheries. The Development of Welfare States in Nineteenth and Twentieth Century Europe (Bern: Peter Lang), 218-219; Annola, Äiti, emäntä, virkanainen, vartija, 42-44.

${ }^{20}$ Jaakkola, Vaivaisten holhouksesta köyhäinhoitoon, 138; Mirja Satka (1995) Making Social Citizenship: Conceptual Practices from the Finnish Poor Law to Professional Social Work (Jyväskylä: Jyväskylä University Printing House), 3537. It should be noted that the workhouse system did have its shortcomings in England too. It failed, for example, to remedy poverty caused by temporary unemployment in the most industrialised parts of the country. Moreover, as Steven King and Geoff Hooker suggest, outdoor relief remained a norm both in England and in Wales. Hooker, Llandilofawr Poor Law Union, 294; King, Poverty, Medicine and the Workhouse, 233; Fraser, The Evolution of the British Welfare State, 58-59.
} 


\section{Workhouse Management and Maternalist Discourse}

This section looks at the ways in which Finnish state officials and the Finnish Women's Association (FWA) used the maternalist discourse to promote female leadership in workhouses. Overall, the discussion illuminates the extent to which this discourse built on contemporary understandings of feminine and masculine duties that were inextricably linked to ideas of class.

The English and Welsh Poor Relief Unions were monitored by the Local Government Board and its predecessors. In 1888, Finland became the first of the Nordic countries to introduce a similar supervisory state official, the Inspector of Poor Relief. In 1902, the machinery was extended by introducing three regional Instructors of Poor Relief, who reported to the Inspector. The responsibilities of the small Finnish Inspectorate resembled those of the Local Government Board: both were to ensure that the existing poor relief and health legislations were observed on a local level, and to give tutelage to local authorities on poor relief. The Inspectorate particularly monitored those municipal workhouses that were funded by the state. ${ }^{21}$

The Finnish Inspectorate emphasised early on that a workhouse was not a prison but rather a place where able-bodied paupers would learn basic virtues such as cleanliness, godliness and orderliness, through a disciplined way of life. ${ }^{22}$ In other words, poor relief was linked with civic education. Similar ideas had been expressed in England, especially after the workhouses were opened to visitors in 1860 and the election of the first female and working-class guardians of the poor in the $1890 \mathrm{~s}^{23}$ It is probable that the Finnish Inspectorate benefitted from experiences in England and other countries to build a workhouse system with a similar ambitious purpose.

\footnotetext{
${ }^{21}$ Peter Wood (1991) Poverty and the Workhouse in Victorian Britain (Bath: Alan Sutton), 83; Christine Bellamy (1988) Administering Central-Local Relations, 1871-1919: the Local Government Board in its Fiscal and Cultural Context (Manchester: Manchester University Press); Fraser, The Evolution of the British Welfare State, 60-65; Fowler, The Workhouse, 11-15; Johanna Annola (2016a) The Initiation of State Control of Poor Relief in Finland and Sweden, 18801920, Revue d'histoire nordique No 22, 203-222; Annola, Äiti, emäntä, virkanainen, vartija, 46.

${ }^{22}$ G. A. Helsingius (1899) Handbok i fattigvård (Helsinki: J. Simelii arfvingars boktryckeri aktiebolag), $108 ;$ G. A. Helsingius (1917) Köyhäinhoidon käsikirja (Porvoo: Holger Schildt), 116. In addition to municipal workhouses there were also specific penal institutions for hardened vagrants and other criminals.

${ }^{23}$ Longmate, The Workhouse, 175, 266-267.
} 
According to the Inspectorate, workhouses could only fulfil their aims if they were properly managed. Therefore, the question of workhouse management became a key issue in the early 1890s. For the first Inspector, Gustaf Adolf Helsingius, the success of the workhouse system was also a personal matter - after all, he had been the keenest advocate of workhouses in the 1880s, and his professional future was interwoven with their continuity in Finland. ${ }^{24}$

The size of the Finnish workhouses was the first consideration of the Inspectorate when appointing workhouse managers. According to state officials, small rural workhouses were to be an extension of a private home. This, in turn, rendered them suitable for female leadership. The Inspectorate's idea reflected contemporary maternalist discourse, which argued that women had an inborn aptitude for nurturing. Because women were believed to be natural carers and educators, their place was in the home as devoted wives and mothers, or in the extension of the home as nurses, teachers or social care workers. ${ }^{25}$

From the Inspectorate's point of view, then, an educated woman was well-suited to manage the workhouse on a day-to-day basis. More importantly, because of the alleged nature of women, a matron was also seen as more than suited to turn able-bodied inmates into respectable citizens $^{26}$ and provide care for infirm inmates. While a man could probably manage the first task, he

\footnotetext{
${ }^{24}$ Annola, The Initiation of State Control of Poor Relief, 207-209.

${ }^{25}$ On the ideal of womanhood and separate spheres, see for example Barbara Welter (1966) The Cult of True Womanhood: 1820-1860, American Quarterly, vol. 18, no. 2, part 1, 151-174; Martha Vicinus (Ed.) (1977) A Widening Sphere: Changing Roles of Victorian Women (Bloomington: Indiana University Press); Carroll Smith-Rosenberg (1985) Disorderly Conduct: Visions of Gender in Victorian America (New York: Knopf); Leonore Davidoff \& Catherine Hall (1987) Family Fortunes: Men, and Women of the English Middle Class, 1780-1850 (Chicago: University of Chicago Press); Linda K. Kerber (1988) Separate Spheres, Female Worlds, Woman's Place: The Rhetoric of Women's History, Journal of American History 75, 9-39; Lori D. Ginzberg (1990) Women and the Work of Benevolence: Morality, Politics and Class in the Nineteenth-Century United States (New Haven \& London: Yale University Press); Kai Häggman (1994) Perheen vuosisata: perheen ihanne ja sivistyneistön elämäntapa 1800-luvun Suomessa (Helsinki: Finnish Historical Society); John Tosh (1999) A Man's Place: Masculinity and the Middle-Class Home in Victorian England (New Haven \& London: Yale University Press); Cathy Ross (2006) Separate Spheres or Shared Dominions?, Transformation 23/4.

${ }^{26}$ It should be noted that the concept of 'civic education', 'civic virtues' or 'citizenship' was linked to social stratification: it was generally believed - especially among the upper social strata - that different socio-economic groups had different duties in society. From the Inspectorate's point of view, an adult pauper would be a good citizen if they simply ceased relying on poor relief and chose to lead a life as a decent, god-fearing member of the working population. Thus a pauper was not expected to strive after a more active and more complex form of citizenship, which involved political, societal and cultural participation; such agency was usually reserved for members of the upper social strata. The situation changed in 1906 with the introduction of universal suffrage. Until 1944 regular poor relief, however, was one of the nine grounds for excluding individuals from suffrage. Disenfranchisement was not permanent, as an individual could regain the vote if they ceased relying on poor relief. Minna Harjula (2009) Excluded from universal suffrage: Finland after 1906, in Irma
} 
was seen to lack the motherly attributes for the latter tasks. ${ }^{27}$ When supervising activities considered more masculine - such as the work of male inmates in agriculture and forestry - the matron was normally assisted by a male steward. The supreme power nevertheless rested with the matron largely because the focus was on internal order rather than agricultural productivity. ${ }^{28}$

In campaigning for female leadership, the Inspectorate found an ally in the FWA. The association was established in 1884 and was made up mostly of women of the upper social strata. It lobbied for the improvement of women's educational circumstances, equal judicial status for men and women, equal opportunities to stand for election for administrative offices of the state, the municipalities and the church, equal pay for equal work - and extending the right to vote to those women who were free from male guardianship and met certain property requirements. However, the question of universal female suffrage was not on their political agenda until the turn of the century. ${ }^{29}$ In the early 1890s, the FWA focussed on the promotion of women onto municipal Poor Relief Boards. Women had been eligible to sit on the boards since 1889. The FWA tried to encourage more women to avail themselves of this right by publishing a series of journal articles on the matter. In making its case, the FWA drew upon maternalist discourse, stressing that women's motherly expertise made them particularly suitable for dealing with sick inmates or children and making sure that they would become respectable and industrious citizens and thus preventing the succession of new generations of paupers. An article published in 1889 referred to the experiences in England, explaining that although one 'could question the modernity of the English poor relief system', there had been significant improvement since women had become involved in poor relief. ${ }^{30}$

\footnotetext{
Sulkunen, Seija-Leena Nevala \& Pirjo Markkola (Eds.) Suffrage, Gender and Citizenship: International Perspectives on Parliamentary Reforms (Newcastle: Cambridge Scholars Publishing), 106-108.

${ }^{27}$ Annola, Äiti, emäntä, virkanainen, vartija, 66-82.

${ }^{28}$ Annola, Äiti, emäntä, virkanainen, vartija, 200-201.

${ }^{29}$ Irma Sulkunen (2006) The General Strike and Women's Suffrage, Centenary of Women's Full Political Rights in Finland. Ministry of Social Affairs and Health \& Christina Institute, University of Helsinki. URL: http://www.helsinki.fi/sukupuolentutkimus/aanioikeus/en/articles/strike.htm.

${ }^{30}$ Anonymous (1889) Miksi tulee naisia valita vaivaishoitohallitukseen? Koti ja yhteiskunta, October 15. Similar rhetoric was invoked to justify female participation in local poor relief in England. In the late 1880s, women's involvement in poor relief took the form of workhouse visiting committees and voluntary organisations. Administrative positions were not open to women until 1894, when the property qualification for people seeking election as Poor Law Guardians was
} 
The writer was most likely Alexandra Gripenberg, chairwoman of the FWA and the editor-in-chief of the journal in question. She was well-connected and had travelled widely in Britain and elsewhere in Europe. ${ }^{31}$ Gripenberg's article reflects the fact that there was a fifty-year time gap between the poor relief reforms in England and Finland, and although the problems concerning, for instance, the competence of workhouse management had been discussed in England early on, the debates only truly began to bear fruit towards the end of the century. Because of this, the English system could appear as both exemplary and static at the same time in the eyes of a late nineteenthcentury Finnish observer.

The FWA's decision to collaborate with the Inspectorate to promote women's involvement in poor relief both as poor relief board members and as workhouse matrons is understandable. Earlier research has suggested that female reformers were likely to be more successful if their maternalist causes were taken up by male actors, who often pursued other goals such as national efficiency and control of the labour force. ${ }^{32}$ It seems, however, that in the Finnish case the rhetoric of the two collaborating parties were almost identical, and that it was in both their interests to work together for a common goal: the battle against pauperism, in which female involvement in poor relief could prove to be a decisive factor. Moreover, it is probable that the FWA had a motive of their own: once women proved their worth in poor relief, other administrative roles might equally be opened to them.

While the FWA agreed to raise interest among the group of eligible women, the Inspectorate was to set up administrative processes to ensure that women were duly appointed by municipalities. In 1892, these two parties turned to an esteemed author to write an eloquent appeal to Finnish women to claim their rightful place in poor relief. The appeal was circulated in municipalities

\footnotetext{
abolished. Steven King (2004) 'We Might Be Trusted': Female Poor Law Guardians and the Development of the New Poor Law: The Case of Bolton, England, 1880-1906, International Review of Social History, vol. 49, no 1, 29. See also Patricia Hollis (1987) Ladies Elect: Women in English Local Government 1865-1914 (Oxford: Clarendon).

${ }^{31}$ Venla Sainio (2004) Aleksandra Gripenberg, in Suomen kansallisbiografia 3 (Helsinki: Finnish Literature Society), 288-289.

${ }^{32}$ Koven and Michel, Womanly Duties, 1080.
} 
and also published in newspapers and in the FWA's journal. ${ }^{33}$ Towards the end of the century, the ideal female workhouse leader envisioned by state poor relief officials and the FWA was disseminated through guidebooks, pamphlets and journal articles and also articulated through the comments that officials made on municipalities' choices of matrons.

Social class played an important role in the campaign for female leadership in workhouses: the appeal was clearly intended for upper- or middle-class women. ${ }^{34}$ From the state's point of view, a workhouse matron had to be cultivated enough to share the Inspectorate's understanding of basic civic virtues and charismatic enough to claim authority over the inmates. In 1892, the Inspectorate introduced competency requirements for workhouse matrons, which included literacy, housekeeping, nursing, mental health nursing, childcare and bookkeeping. Until the 1920s there was no bespoke training available for matrons, which is why applicants had to decide what courses to take or where to practise in order to meet the requirements. In the early stages of the workhouse system, then, educational requirements were such that lower-class women were ineligible to apply. ${ }^{35}$ This stood in sharp contrast to the mid-nineteenth-century English Poor Law Commissioner's vision of a workhouse matron as someone comparable to a 'trustworthy female servant'.36

\footnotetext{
${ }^{33}$ Anonymous (1915) Ett inlägg i fattigvårdsfrågan av Z. Topelius, Åbo Underrättelser, December 5-6; Gustaf Adolf Helsingius (1918) Fattigvårdens nydaning i Finland under tre årtionden (Helsinki: Schildts), 39. The author was Zachris Topelius, who had made a career in the Imperial Alexander University of Helsinki but also became famous for his nationalist children's books. His view on women's duties at home and in society were infused with maternalist rhetoric. Pasi Jaakkola (2011) Topeliaaninen usko: Kirjailija Sakari Topelius uskontokasvattajana. PhD thesis, Faculty of Theology, University of Helsinki, 137-139.

${ }^{34}$ It has been argued that the Finnish middle class during this period consisted of various groups lacking a defined class consciousness. Most individuals who belonged to this socioeconomic group can nevertheless be characterised by their shared belief in education as a means for social advancement. The lower part of the middle class consisted of wealthier freeholder peasants, artisans, petty bourgeoisie as well as lower-ranking white-collar employees with a certain level of education. The upper part on the middle class comprised, first, wealthier entrepreneurs and second, individuals with academic degrees, such as grammar school teachers, doctors, lawyers, clergymen and higher officials. Risto Alapuro (1985) Yhteiskuntaluokat ja sosiaaliset kerrostumat 1870-luvulta toiseen maailmansotaan, in Tapani Valkonen et al. (Eds.) Suomalaiset: Yhteiskunnan rakenne teollistumisen aikana (Helsinki: WSOY), 70-73; Pertti Haapala (1995) Kun yhteiskunta hajosi (Helsinki: Painatuskeskus), 99-127.

${ }_{35}$ Annola, Äiti, emäntä, virkanainen, vartija, 66-82.

${ }^{36}$ Poor Law Commissioners' expression as quoted in Crowther, The Workhouse System, 117.
} 
As early as in the mid-1890s, the majority of municipalities had a matron instead of a master or a married couple in charge of the workhouse. This development was largely an economical decision as women could be paid a lower wage than men. ${ }^{37}$ Female management of workhouses opened up new opportunities for women's agency ${ }^{38}$ - but this was not without problems. A female leadership position, even while grounded in maternalist discourse, conflicted with the prevailing gender hierarchies or local practices. As a result, the appointment of matrons raised various complexities.

The Finnish poor relief system as a whole was a hierarchical structure: while most small rural workhouses were managed by women, men usually occupied top positions in larger workhouses, which, in fact, resembled more those in England and Wales. ${ }^{39}$ While the Inspector of Poor Relief never explained why 'larger urban workhouses should be managed by a master', ${ }^{40}$ it appears that he did not think women were suitable because of their motherly nature. He presumably thought that urban workhouses were comparable to other large institutions such as hospitals, prisons and garrisons, the management of which required the brain of a man not the heart of a woman. In these cases, a female housekeeper or a nurse was appointed to assist the master.

The local Poor Relief Boards were often slow or reluctant to follow the instructions given by the state poor relief authorities. This points to an unclear demarcation line between state

\footnotetext{
37 Annola, Äiti, emäntä, virkanainen, vartija, 77-83, 124; Johanna Annola (2013) Valtiovalta köyhäintalon johtajan ammatin rakentajana, 1880-1921, Janus, vol. 21, no. 3, 195.

${ }^{38}$ For more on how taking up that role affected individual women's lives, see Johanna Annola (2016b) Out of Poverty: The Ahrenberg Siblings, 1860-1920, Journal of Finnish Studies, vol. 20, no. 1, 132-163; Johanna Annola (2018) Female Biographies, Social Service and Social Mobility, in Daniel Nyström \& Johanna Overud (Eds.) Gender, History, Futures: Report from the XI Nordic Women's and Gender History Conference, Stockholm, Sweden, 2015 (Umeå: Sveriges kvinnooch genushistoriker), 40-49. URN: urn:nbn:se:umu:diva-148406.

${ }^{39}$ Similar gender ideas underpinned the decision to appoint only men to the Inspectorate. It was not until 1917 before the first Female Assistant Inspector was appointed, whose focus, influenced by maternalist discourse, was on all issues relating to women and children. Yet this new office was an important step in women's participation in the state administration of poor relief and heralded the growing importance of maternal and child welfare in Finnish social policy. On the other hand, the office was not about extending female participation beyond the maternalist discourse but simply extending the maternalist discourse to the state administration. Johanna Annola (2016c) Elli Tavastähti ja 1920 luvun sosiaalipolitiikka maailmankuvien murroksessa, in Irma Sulkunen, Marjaana Niemi \& Sari Katajala-Peltomaa (Eds.) Usko, tiede ja historiankirjoitus: Suomalaisia maailmankuvia keskiajalta 1900-luvulle (Helsinki: Finnish Literature Society), 134, 156-164.

${ }^{40}$ Helsingius, Handbok i fattigvård, 66.
} 
control and the traditional sphere of municipal self-government on the one hand and different views on the aims of the workhouse on the other. It appears that some Boards did not regard the workhouse as a specific tool for civic education but more as an ordinary farm. In these cases, the (male) members of the Board often allied themselves with the steward, with whom they shared an interest in improving the agricultural productivity of the institution. ${ }^{41}$ If farming became the chief-priority in a workhouse, then the importance of internal order was diminished and the matron's authority was subordinate to that of the steward.

In other cases, the Boards decided to appoint a married couple instead of a matron and a steward - or allowed these two to marry each other. ${ }^{42}$ The state officials, however, did not think that married couples made good workhouse managers because, according to them, there were only a handful of couples in which both husband and wife were competent at their specific tasks. ${ }^{43}$ More importantly, according to the prevailing patriarchal way of thinking, a husband was the head of the family, which is why a marriage nullified a matron's claim to a leadership position in the institution. Her space was reduced to that of an ordinary wife and the alleged benefits of female leadership would be lost.

The Inspectorate lacked the authority to forbid local Boards from increasing the agricultural productivity of the workhouse or appointing married couples, because this did not expressly violate existing poor relief and health legislations. The state officials nevertheless tried to minimise the risk of clashes by emphasising that the occupation of a workhouse matron was primarily intended for unmarried women. ${ }^{44}$ This contrasted with the development in England, where married couples were preferred to unmarried workhouse masters and matrons. ${ }^{45}$ The difference was due to a

\footnotetext{
${ }^{41}$ The National Archives of Finland, The Archives of the Inspector of Poor Relief, Correspondence with Municipalities Fb: $1-40$.

${ }^{42}$ Annola, Äiti, emäntä, virkanainen, vartija, 86, 206-212.

${ }^{43}$ Helsingius, Handbok i fattigvård, 72; Helsingius, Köyhäinhoidon käsikirja, 90-91. Similar arguments were presented in England in the early 1900s by Sidney and Beatrice Webb. Crowther, The Workhouse System, $1981,116$.

${ }^{44}$ G. A. Helsingius (1891) Nainen vaivaishoidon palveluksessa, Koti ja Yhteiskunta, no. 11; The National Archives of Finland, The Archives of the Inspector of Poor Relief, Correspondence with Municipalities Fb: 1-40.

${ }^{45}$ Crowther, The Workhouse System, 116, 143.
} 
different understanding of the division of labour between the matron and male workhouse staff. As the duties of an English workhouse matron were similar to those of an ordinary wife, marriage was not seen there as a problem. But as a Finnish matron was expected to run the whole institution, marriage was deemed an obstacle.

\section{Maternal power and Care in the Workhouse}

Early research on English workhouses has often portrayed these institutions as mere prisons managed by cruel or at best indifferent officials. ${ }^{46}$ More recent studies, however, have shifted the focus of the research towards interactions between inmates and staff, and have paid attention also to the more positive experiences of inmates. ${ }^{47}$

According to David R. Green, there existed 'an unspoken balance of expectations between inmates and officials' in the early nineteenth-century London workhouses. While the officials expected respect from the inmates, the latter expected humane treatment from the staff. ${ }^{48}$ A similar power structure, a 'symbolic contract', has been identified by Anna Jansdotter and Pirjo Markkola in their work on the relationship between nineteenth-century Nordic female philanthropists and the 'fallen' women they were trying to 'uplift'. While the women entered a shelter voluntarily, they had to agree to obey the regulations specified by the matron of the institution. In other words, the matron agreed to work for the women's well-being only if they agreed to work with her. ${ }^{49}$

By the end of the nineteenth century, the Finnish Inspectorate aimed to create a similar 'symbolic contract' by providing workhouse matrons with detailed instructions on how to deal with

\footnotetext{
${ }^{46}$ Crowther, The Workhouse System, 134-135; Fowler, The Workhouse, 65.

${ }^{47}$ David R. Green (2006) Pauper Protests: Power and Resistance in Early Nineteenth-Century London Workhouses, Social History, vol. 31, no. 2; Jane Humphries (2010) Childhood and Child Labour in the British Industrial Revolution (Cambridge: Cambridge University Press), 323-326; Humphries, Care and Cruelty in the Workhouse, 120-121, 123, 126; King, Poverty, Medicine and the Workhouse, 246; Tomkins, Workhouse Medical Care, 91-99.

${ }^{48}$ Green, Pauper Protests, 139, 145.

49 Anna Jansdotter (2004) Ansikte mot ansikte: Räddningsarbete bland prostituerade kvinnor i Sverige 1850-1920 (Stockholm \& Stenhag: Symposion), 25-26. See also Pirjo Markkola (2011) Women's Spirituality, Lived Religion, and Social Reform in Finland, 1860-1920, Perichoresis, vol. 9, no. 2, 160-161.
} 
the inmates in order to build the trust needed to calm them and instil in them the idea of selfimprovement. ${ }^{50}$ This section analyses the practical instructions workhouse matrons received from state officials in order to succeed in their task. It highlights the link between power and care in a matron's work and explores the challenges matrons faced on a day-to-day basis. As such, this section explores the workings of maternalism in the workhouse.

In order to be able to manage a workhouse, a matron had to be sufficiently authoritative to undertake motherly interventions in the inmates' lives. Her authority was not to be constructed by brute force: cruelty and indifference would only cause the inmates to resist any kind of change, which would eventually imperil the success of the workhouse system. Rather, a matron was to claim authority over the inmates by displaying her moral and social superiority in subtler ways, which would not break the trust between her and the inmates.

To achieve such authority, a matron first of all had to lead an exemplary life, especially she had to remain chaste and sober, which were essential markers of upper- and middle-class female respectability. A chaste and sober matron furthermore was expected to lead through example. Similar to the English workhouses, male and female inmates were accommodated in separate premises to prevent them from having sexual relations with each other but they could nevertheless mix easily. A chaste matron, then, it was assumed, would encourage decent behaviour in the inmates through her own example. ${ }^{51}$ Sobriety was also a key feature of poor relief institutions because drink was regarded as one of the main reasons why able-bodied adults had failed to support themselves and their

\footnotetext{
${ }^{50}$ Helsingius, Nainen vaivaishoidon palveluksessa; Helsingius, Handbok i fattigvård, 71-72; Helsingius, Köyhäinhoidon käsikirja, 89-90.

${ }^{51}$ The Rules of Procedure for the Inspector of Poor Relief in Finland, 9 October 1888, 1-2; Helsingius, Handbok $i$ fattigvård, 61-62; Helsingius, Köyhäinhoidon käsikirja, 79; Longmate, The Workhouse, 89; Fowler, The Workhouse, 42, 87. For contemporary middle- and upper-class understanding of chastity, see Pirjo Markkola (2000) The Calling of Women: Gender, Religion and Social Reform in Finland, 1860-1920, in Pirjo Markkola (Ed.) Gender and Vocation: Women, Religion and Social Change in Nordic Countries, 1830-1940 (Helsinki: Finnish Literature Society); M. J. D. Roberts (2004) Making English Morals: Voluntary Association and Moral Reform in England, 1787-1886 (Cambridge: Cambridge University Press); Mariana Valverde (2008) The Age of Light, Soap and Water: Moral Reform in English Canada, 1885-1925, second edition (Toronto: University of Toronto Press).
} 
dependents and ended up as paupers. ${ }^{52}$ Again a sober matron would lead by example.

Second, a matron was to emphasise her superiority by clearly demarking the boundaries between herself and the inmates. This meant first of all that she was to dress 'like the mistress of the house, not like a maidservant' ${ }^{53}$ In addition, she was expected to communicate with the inmates the same way the members of the upper social strata addressed their servants: kindly, but with an air of distance. When giving orders, furthermore, the matron had to be firm. A good matron never hesitated, changed her mind or cancelled an order she had given nor in the case of conflict should she argue with others. ${ }^{54}$ If a matron had to punish an inmate, calm conduct was especially important. It was crucial that inmates understood that punishment was not the matron's personal revenge. They had to see the matron as an instrument through which society disciplined errant individuals. No matter how stressful the situation, the matron was not permitted, for example, to restrain an inmate. She was to announce the punishment in a composed and impersonal tone, after which the steward or other members of the staff implemented the punishment. ${ }^{55}$

State officials envisioned a matron as a motherly friend to the inmates. Her compassion was to be reserved for the infirm and the able-bodied inmates alike. This comes particularly to the fore in the protocol for the entry of paupers into a workhouse. On the one hand, the protocol mirrored that in England: newcomers were forced to hand over their personal belongings, such as money or clothes. They were then given a bath, and in some cases their hair was also cut, and finally they had to change into a workhouse uniform. Yet on the other, the protocol stipulated that the matron had to greet newcomers personally and express her interest in their - often difficult - situation, even if such a sympathetic gesture would probably result in 'long and dull lamentations' or even lies on the

\footnotetext{
${ }^{52}$ Fowler The Workhouse, 9-10; The National Archives of Finland, The Archives of the Inspector of Poor Relief, Registers on Paupers Bc:5; Helsingius Handbok i fattigvård, 3, 111-112.

${ }^{53}$ Helsingius, Handbok $i$ fattigvård, 89. It was assumed that slender, timid-looking women did not make good matrons because they would lack the authority needed.

${ }^{54}$ Helsingius, Handbok i fattigvård, 87-88; Helsingius, Köyhäinhoidon käsikirja, 98. In a way, matrons were to use these instructions to provide the paupers with a performance of respectable womanhood, see Johanna Annola, Äiti, emäntä, virkanainen, vartija, 11, 79-80. For the concept of performance, see Judith Butler (1993) Critically Queer, GLQ: A Journal of Lesbian \& Gay Studies, vol. 1, 21-22.

${ }^{55}$ Helsingius, Handbok i fattigvård, 91; Helsingius, Köyhäinhoidon käsikirja, 106-107.
} 
paupers' part. According to the Inspectorate, the matron's kindness would serve as a remedy for the foregoing humiliating procedures. ${ }^{56}$

The inspectorate's insistence that the matron should develop an emotional closeness with the inmates was not unique. As Nicola Sheldon has shown on children in institutional care in England in the 1870s, there was generally an emerging awareness of the benefits of establishing a personal relationship between a poor relief officer and paupers, especially with regard to pauper children. According to Sheldon, it was argued that if a pauper child bonded with an adult, it would become significantly harder for him or her to break the rule for fear of disappointing the caretaker. ${ }^{57}$ In other words, emotional closeness was effectively a tool for manipulation.

Not all inmates, however, embraced the matron as their 'friend'. A matron's motherly interventions often conflicted with the mothering of unmarried pauper women, who stayed in the workhouse in between jobs or pregnancies. ${ }^{58}$ As younger children usually stayed with their mother in the workhouse, there was, then, real potential for a clash over childrearing between the mother and matron. Underpinning any conflict between matrons and mothers was the assumption that unmarried mothers were morally corrupt women and thus deemed unfit mothers. Accounts by the Inspectorate and matrons themselves suggest that unmarried mothers were arrogant and indifferent towards the matron. By rejecting the motherly care provided by a matron or by downright seeking confrontations, they posed a challenge to the matron's authority. ${ }^{59}$ In other words, these women ignored or violated the 'symbolic contract' between them and the matron.

Inmates, then, were not powerless. More generally, they resisted a matron's authority by behaving in a disruptive fashion or even with violence, refusing to perform their daily work,

\footnotetext{
${ }^{56}$ Helsingius, Handbok i fattigvård, 96; Helsingius, Köyhäinhoidon käsikirja, 99; Longmate, The Workhouse, 93.

${ }^{57}$ Nicola Sheldon (2013) 'Something in the Place of Home': Children in Institutional Care, 1850-1918, in Nigel Goose \& Katrina Honeyman (Eds.) Childhood and Child Labour in Industrial England: Diversity and Agency, 1750-1914 (New York \& London: Routledge), 272.

${ }^{58}$ See also Levine-Clark, Engendering Relief, 120-123.

${ }^{59}$ The National Archives of Finland, The Archives of the Inspector of Poor Relief, Correspondence with Municipalities $\mathrm{Fb}: 1-40$.
} 
leaving the workhouse without a permission, or making complaints about the matron to the local Poor Relief Board or the Inspectorate. ${ }^{60}$ This echoes David R. Green's notion of 'pauper power', i.e. the ways in which inmates of early nineteenth-century London workhouses resisted the authorities. ${ }^{61}$ By the early 1900s, Finnish paupers found a strong advocate of their cause in the social democrats, who collected inmates' complaints and published them in newspapers. The social democrats regarded the workhouse system as a prime example of unequal power in municipal decision-making bodies and the oppression of the poor and were thus eager to provide the inmates with an opportunity to appeal to public opinion. For matrons, their interventions could be extremely stressful, especially if accusations led to an investigation. ${ }^{62}$

A matron's kindness always had to coexist with authoritative behaviour. Alternatively, her authority would be compromised if she was too soft or emotional. ${ }^{63}$ On a day-to-day basis a workhouse matron's fight against excessive emotions was particularly present in her relationship with pauper children. Part of the problem was that children over three were allowed in a workhouse only if there was a separate orphanage annexed to the institution. ${ }^{64}$ The rule was based on the assumption that the workhouse was not an appropriate environment for children because of the potentially negative influence from the older inmates. ${ }^{65}$ It was also assumed that if children spent their early years in an institution, they would later find it hard to adapt to life outside. In this sense, placing pauper children in good foster homes was regarded a far better option. ${ }^{66}$

\footnotetext{
${ }^{60}$ The National Archives of Finland, The Archives of the Inspector of Poor Relief, Correspondence with Municipalities Fb: $1-40$.

${ }^{61}$ Green, Pauper Protests, 138, 157.

${ }^{62}$ Johanna Annola, Äiti, emäntä, virkanainen, vartija, 234-239. Finland introduced universal suffrage in national elections in 1906. Universal suffrage in local elections was not implemented until 1917. Prior to that, the right to vote was based on property qualifications.

${ }^{63}$ The National Archives of Finland, The Archives of the Inspector of Poor Relief, Correspondence with Municipalities Fb: 1-40; Helsingius, Handbok i fattigvård, 89.

${ }^{64}$ The Rules of Procedure for the Inspector of Poor Relief in Finland, 16 August 1893, 5.

65 This was mostly not the case in small rural institutions where there was not enough room to segregate paupers by age. In this regard, the Finnish nineteenth-century workhouses resembled the smaller Old Poor Law workhouses in England. Ottaway, The Elderly in the Eighteenth-Century Workhouse, 49.

${ }^{66}$ The Annual Report of the Inspector of Poor Relief 1894, 21; the National Archives of Finland, the Archives of the Inspector of Poor Relief, Correspondence with Municipalities Fb: 1-40; Helsingius, Handbok i fattigvård, 151-154; Helsingius, Köyhäinhoidon käsikirja, 151-155; Johanna Annola (2015) The Conflict Between Lived Religion and State
} 
As municipalities were slow in building orphanages or placing children in foster homes,${ }^{67}$ their presence in workhouses became a challenge for matrons. Not only was it difficult for matrons to keep children away from adult inmates, they also often became emotionally attached to them. The source material contains various accounts of matrons trying to keep their protégés in the institution against the orders of the Inspectorate, often claiming that the child in question was a foster child or 'just a servant girl'. Referring to the Rules of Procedure, the Inspectorate bluntly rejected all requests it found inadequately justified. ${ }^{68}$

However, as the Inspectorate lacked the authority to forbid a matron to raise a child in her private quarters at the workhouse, some matrons did indeed have foster children or even children of their own (in case they were married or widowed). The Inspectorate, however, often argued that such arrangements would not work well because it was almost impossible to bring up a child while taking proper care of the workhouse. ${ }^{69}$ For the Inspectorate, then, there was a conflict between a matron's authoritative motherliness and the ideals of motherhood. State officials believed that mothers would never make good workhouse matrons because they were constantly occupied with their own family and household: an ideal matron was not a real mother but was motherly and her care would act as a tool for civic education. The Inspectorate, then, firmly believed, as wider society, that women were only able to exercise one vocation.$^{70}$

Control of Poor Relief: The Case of Emma Mäkinen's Private Orphanage, Perichoresis, vol. 13, no. 2, 77-96. DOI: https://doi.org/10.1515/perc-2015-0011.

67 Jaakkola, Vaivaisten holhouksesta köyhäinhoitoon, 134-135.

68 The National Archives of Finland, the Archives of the Inspector of Poor Relief, Correspondence with Municipalities Fb: $1-40$.

${ }^{69}$ The National Archives of Finland, The Archives of the Inspector of Poor Relief, Correspondence with Municipalities Fb: 1-40; see also Fowler 2014, 52.

${ }^{70}$ Irma Sulkunen (1995) Mandi Granfelt ja kutsumusten ristiriita (Helsinki: Hanki ja Jää), 33-37. 


\section{Conclusion}

This article has discussed the ways in which state poor relief officials and the FWA used maternalist discourse to justify and promote female leadership in Finnish workhouses at the end of the nineteenth century. Moreover, the article has explored maternalist practice in workhouses by discussing the instructions for matrons drawn up by state officials.

This article joins Rebecca Jo Plant and Marian van der Klein in suggesting that not all female agency grounded in maternalist discourse falls within the scope of 'activism'. Instead of drawing a strict line between activism and conservatism, a more 'organic' approach could be useful: the case of the Finnish workhouse matron indicates that although there were conservative elements associated with this role, it nevertheless contained steps towards women's emancipation.

The position of a Finnish workhouse matron can be regarded as a new kind of leadership

role for women. However, it does not at first glance appear emancipatory. The position was built upon a discourse, at the heart of which lay the upper social strata's perception of women as naturalborn providers of care and education. Workhouse matrons therefore joined the ranks of women, who were expected to use their motherly authority to create an orderly society. Matrons were preferably recruited from among the upper echelons of society because state poor relief authorities and the FWA believed that this group defined and guarded the ideals of respectable citizenship.

By taking a closer look at the instructions state officials gave to workhouse matrons as well as the conflicts that arose in a matron's everyday work - this article has revealed that the occupation of a matron drew upon and helped to perpetuate dominant upper- and middle-class ideals of womanhood. The virtues of a good workhouse matron included among others precision, orderliness, cleanliness, sobriety and chastity. Moreover, there existed strict rules of conduct in order to prevent collisions between female workhouse mangers and male agents in poor relief . 
The rules outlined the boundaries of a matron's sphere and implied that by crossing them, she would be considered unprofessional. But this article has also highlighted that state officials promoted professionalism by clearly distinguishing between actual and symbolic motherhood. Their ideal matron embodied some characteristics of good mothers, such as being tender-hearted, but at the same time they could not perceive a woman to be dedicated to more than one occupation. Therefore actual mothers were not deemed to make good workhouse matrons as they could not dedicate themselves fully to turning paupers into respectable citizens.

\section{Acknowledgements}

I would like to thank the University of Oxford History Faculty for receiving me as an academic visitor in 2016, and particularly Professor Emerita Jane Humphries (All Souls College, Oxford) for encouraging me to write this article. I would also like to thank Professor John Tosh (University of Roehampton), Professor Pirjo Markkola (University of Tampere) as well as the two anonymous readers for kindly providing me with excellent comments.

\section{Funding}

This research was undertaken as a part of my work as a Research Fellow in the Finnish Centre of Excellence in Historical Research (2012-2017), which was funded by the Academy of Finland. 